\title{
STUDENTS' ABILITY IN WRITING DESCRIPTIVE TEXT BASED ON ITS GENERIC STRUCTURE AT THE TENTH GRADE STUDENT OF VOCATIONAL HIGH SCHOOL
}

\author{
Novia Sartika ${ }^{1}$, Mochamad Nurdin ${ }^{2}$ \\ ${ }^{1}$ IKIP Siliwangi \\ 2 IKIP Siliwangi \\ ${ }^{1}$ noviasartika14@gmail.com, ${ }^{2}$ nurdinmochamad23@gmail.com
}

\begin{abstract}
Study of language skills in English is pretty important to increase students' skill in study English. One of the most important skills is writing. It can make students share the ideas into written form in the text or paragraph with the right order of generic structure. The purposes of this study are to find out the students ability in writing descriptive text and to find out whether students writing descriptive are already well organized or not. The research method used qualitative research method. The researchers took 33 students as respondents. The data analysis took from the students' descriptive text results. Based on the data analysis, the researchers found 15 or $45 \%$ students created the descriptive text and 18 or $55 \%$ students created the report text. It showed 10 or $30 \%$ students created the paragraphs of descriptive text properly based on its generic structure and 5 or $15 \%$ students could not apply it properly. It can be concluded that most of the students' paragraphs are well organized. Meanwhile, the other students could not make it properly, because they still confused and could not distinguish the differences between descriptive text and report text.
\end{abstract}

Keywords: Writing, Descriptive text, Generic structure

\section{INTRODUCTION}

Language skills are the tools or human ability to deliver messages and give information to other people. One of the purposes of language skill is to communicate with each other. It can be a spoken language or written language. There are four language skills in English such as listening, speaking, reading and writing (Nisa, 2015:79). Writing is an important skill that has to be controlled by the students. Meanwhile, According to Zamel (2007: 207 as cited by Nisa, 2015:79) "writing is a process which the people can explore and discover their thoughts and ideas in written form." In addition, Nunan (2003 cited in Rizqiya, Pamungkas, \& Inayah, 2017: 256) stated that "Writing is an activity that involves physical and mental actions."

Zamel in Nunan (1991: 88) in Mundriyah and Parmawati (2016) states that writing skill can develop rapidly when students' concerns and interests are acknowledged, when they are given numerous opportunities to write. From the theories above, it can be assumed that writing is very important skill because we have to express and share the ideas into written form in the text or paragraphs with the right order of generic structure, that can be read or understood by the readers.

There are twelve genres of text, those are descriptive text, recount text, narrative text, procedure text, explanation text, discussion text, news item, information report, anecdote, 
analytical exposition text, and hortatory exposition text. The researchers focus on the descriptive text which is taught in the first year of high school.

Descriptive text is the text that describes the characteristic of something. Wyrick (1999: 227) states that "the writer of description creates a word picture of person, place, objects, and emotions using a careful selection of detail to make an impression on the reader". From the information above, the researchers got the conclusion that the descriptive text is a kind of texts which describes the characteristics, definition about something, object, certain places or person.

The researchers conduct this research in tenth-grade students of vocational high school, the data collected from thirty-three students. Students have a good enthusiasm in learning descriptive text, the researchers collect the data while during the learning process in the period $3 \times 45$ minutes. In this research, the researchers asked the students to write a descriptive text. The students should give information about the topic include the definition, characteristics, and where the place is taking place based on the topic. For example, if the student wants to describe the place, then he or she should have knowledge about it, such as the location or where the place is, the history, and the characteristics.

The researchers are interested to find out students ability in writing a descriptive text based on its generic structure. The generic structure is arranged or stages in making the descriptive text in order to have a good structure. According to Paltridge (1996), Generic Structure is a general form of a genre; each genre has its own generic structure. It describes the structure of text based on its internal patterning of the rhetorical organization.

There are two generic structures of descriptive writing: identification and description. Identification is to introduce the person, place and the object while the description gives the detail of the person, place, and the object described. It means the students can give the characteristic of the topic that will be described.

The issues to be discussed in this research are summarized in the following research questions; (1) how are the students' ability in writing the descriptive text? (2) are students writing descriptive already well organized?

The research used qualitative descriptive research. The source of data got from students' writing descriptive texts. Then researchers analyzed it based on their ability. In this research used the test to collect the data. After the data had been collected, the researchers want to know students ability in writing a descriptive text based on its generic structure.

Based on the explanation above, the researchers focus on the students' ability in writing a descriptive text based on its generic structures. the research conducted this research entitled "Students Ability in Writing Descriptive Text Based on its Generic Structure at the Tenth Grade Student of Vocational High School.

\section{METHOD}

In this research the researchers used qualitative method. According to Sugiono (2017: 9) "qualitative research method is a research method based on positive philosophy used to examine the condition of natural objects where researchers are as a key instrument." The purpose of a qualitative method is to illustrate an explanation with certainty. 


\section{RESULTS AND DISCUSSION}

\section{Results}

The researchers utilize students ability in writing descriptive text as the data sources. The issues to be discussed in this research are summarized in the following research questions; (1) how are the students' ability in writing the descriptive text? (2) are students writing descriptive already well organized?

The researchers make a solution for a matter of time in teaching so that students get sufficient time in creating a descriptive text. The researchers used two hours at the beginning of the learning process to explain clearly about descriptive text and the generic structure of it until the students are understood. Next, the researchers gave one hour for students created the descriptive text because they need quite a long time to created the paragraphs.

The following is the formula of percentage in getting a result of this research:

$$
P \frac{f 0}{n} \times 100
$$

$\mathrm{F} 0=$ Frequency observed

$\mathrm{N}=$ the number of samples

From the data, there were 33 students gave the result of the test. it showed that most of the students still can not distinguish between descriptive text and report text, because the report text has a resemble characteristics, especially in its purpose such as to describe the things, but the things that can be distinguished between report text and descriptive text is the specifically. The descriptive text is a more specific description than report text that describes the things generally.

It showed 15 or $45 \%$ students created descriptive text and 18 or $55 \%$ students created report text. For students who created descriptive text most of them can apply properly the paragraph of descriptive text based on its generic structure, it showed 10 or $30 \%$ students created it properly and 5 or $15 \%$ students cannot apply it properly, they not made a paragraph but made points for every generic structure of descriptive text

The following is the example of students who created descriptive text properly and students who still can not make a paragraph properly.

\section{Student 1:}

\section{Pet}

I have a cat as my pet. He is really playful, he loved to play with me and the new things he found.

He has orange and white fur, his fur is soft and I like to rubs it for him. He has a long tail. He likes to play with it. He is also always try to catch his tail sometimes. 
In the text above, the student created the paragraph properly with gave the part of identification with gave the information about his pet that is a cat in the first paragraph.

In the second paragraph, the student created the part of description with explained about the characteristics of his pet, and the pet's hobbies.

Student 2:

\section{Favorite Artist}

Identification:

1. My favorite artist is Iwan Fals

2. He is a singer

3. He is handsome

4. And the most preferred song is a Bento

Description:

1. He like to carry a guitar

2. He have a beautiful voice

3. And tall body

In the text above, the student created the paragraph less properly because it showed not a paragraph but in the form of points from each generic structure. In the first point is the part of identification about the information of Iwan Fals as the favorite artist.

In the second paragraph is the point of the description which explained the characteristics of Iwan Fals.

And the following is students who created report text because they still could not distinguish between the descriptive text and report text.

Student 3:

\section{Rabbit}

Rabbit is an herbivore. It is a cute and adorable animal. It is often used as a pet. It is also much loved by people.

Rabbit has four legs, it also has two long ears and also has a thick fur.

Based on the text above, the student created two paragraphs with identified and described the rabbit. In the first paragraph, the student identified the rabbit generally.

In the second paragraph, the student described the characteristics of the rabbit. It included a report text. It means that the student could not distinguish the characteristics and understanding of a descriptive text and report text. 
Student 4:

\section{Giraffe}

Identification:

1. He likes to eat fruit on trees

2. He can be found in Africa

Description:

1. He has a long neck

2. Have four legs

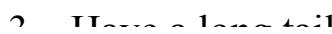

From the text above, the student-created information about giraffe in the lists form. In the first list, the student listed and identified the giraffe generally. Meanwhile, in the second list, the student listed and described the characteristics of the giraffe.

Student 5:

\section{Elephant}

Identification:

1. He is a herbivore animal

2. He eat almost all the vegetables and fruits

Description:

1. The color is grey

2. Have big body

According to the text above, the student created and described the information about Elephant. The student could not write the text organized, because the student wrote it with lists form. In the lists form the student wrote the identification and description. The result of the student's description included as the report text because the student gave the identification generally, meanwhile, the description was the description.

\section{Discussion}

Based on explanation above, it can be conclude that students still have lack knowledge in writing descriptive text because they still cannot distinguish between descriptive text and report text. They were still confused with the generic structure. It is supported by Mardyah (2013), the students writing difficulties in descriptive text are three points. Fisrt, students problem in using generic structure of descriptive text. Second, students difficult in using the lexicogrammatical features of descriptive text. And the last, difficult in descriptive text by students was related lexicogrammatical in using grammar. 
It is also found that the most students's paragraphs were well organized and some students' paragraphs were not well organized because they still have difficulties in structure. It is supported by Haryati (2012) some students in Indonesia still have difficulties to write in English and do some errors in the structure, spelling and lexical meaning.

\section{CONCLUSION}

In finding the students ability in writing a descriptive text based on its generic structure, it answered the first research question (1) How is the students' ability in writing the descriptive text? From the data, the researchers found 15 or $45 \%$ of students created descriptive text and 18 or $55 \%$ of students created report text. It can be concluded that they still could not distinguish between descriptive text and report text. It also answered for the second research question (2) is students writing descriptive text already well organized? From the result showed 10 or $30 \%$ of students created the paragraphs based on its generic structure properly, Meanwhile 5 or $15 \%$ of students could not apply it properly. The researchers concluded that students writing descriptive text are well organized.

\section{ACKNOWLEDGMENTS}

Alhamdulillah all gratitude to Allah S.W.T who gave His blessing to the researchers, so researchers can finish this article with a good health condition. Researchers would like to say the biggest thank you for the supervisor of the research who always gave researcher support when conducting this research. Also, researchers would like to say thank you to IKIP Siliwangi which gave me the opportunity to publish this research. Also for the blind reviewer who reviewed this research as well as. So the editorial team of this research can be published perfectly.

\section{REFERENCES}

Haryati. (2012). An Analysis on the Grammatical Errors in the Students Recount Text Writing. Mardyah, D. et all. (2013). Journal of English Language 1ed. 283.

Mundriyah, M., \& Parmawati, A. (2016). Using Think-Pair-Share (Tps) To Improve Students'writing Creativity (A Classroom Action Research in the Second Semester Students of STKIP Siliwangi Bandung). P2m Stkip Siliwangi, 3(2), 84-91.

Nisa, A. F. (2015). Improving Students 'Writing Skill By Using Inquiry Technique At. 79-86.

Nunan, D. (2003). Practical English Language Teaching. New York.

Paltridge, B. (1996). language learning classroom Brian Paltridge. 50(July), 237-243.

Rizqiya, R. S., Pamungkas, M. Y., \& Inayah, R. (2017). The Use of P.O . W.E.R. Learning As A Learning Strategy To Improve Students Writing Competency. 11(2), 253262.

Sugiono. (2017). Metode Penelitian Kuantitatif, Kualitatif, dan R\&D.

Wyrick, J. (1999). Steps to Writing Well.

Zamel, V. (2007). Writing : The Process of Discovering Meaning. 16(2), 195-209. 